\title{
ON THE POLEMIC OF ACADEMIC INTEGRITY IN HIGHER EDUCATION
}

\author{
Y. Waghid* \\ e-mail: yw@sun.ac.za
}

\section{N. Davids*}

e-mail: nur@sun.ac.za

*Department of Education Policy Studies

Stellenbosch University

Stellenbosch, South Africa

\section{ABSTRACT}

Academic integrity is integral to credible scholarship. Yet, the escalation of publications and the desire to publish, even in this journal - South African Journal of Higher Education - often bring into play the important practice of academic integrity. As the rush for publications increasingly becomes an obsession, rather than an intrinsically loved scholarly activity, the ugly side of academic fraud, cheating and plagiarism begins to accelerate, and this manifests in research outputs. This introductory article takes a critical look at three significant developments in realising research outputs in higher education: Turnitin for turnitout, academic cheating and Google cutting and pasting. We proffer what academics should be doing to avoid the malaise creeping into and manifesting in higher education.

Keywords: higher education, scholarship, academic integrity, plagiarism

\section{INTRODUCTION}

At a recent quality promotion conference organised by the Council on Higher Education (CHE) in South Africa, held at the CSIR International Convention Centre in Pretoria from 26 to 28 February 2019, the advancement of academic integrity in higher education was brought under the spotlight. By far the majority of the papers presented highlighted how academic integrity seems to be undermined in the higher education sector, especially in relation to alleged plagiarism, cheating during tests and examinations, the performance of sexual favours in exchange for better academic assessment scores, the use of ghost writers who are hired by persons to write theses or articles on their behalf, and other ethical dilemmas. The purpose of this article is not to delve into a discussion of the afore-mentioned ethical predicaments, but 
rather to offer some reflection on what seems to be wrong with higher education on the continent, and perhaps elsewhere.

\section{THE CASE OF TURNITIN}

This journal has been using the Turnitin software to detect similarity indexes of articles submitted for consideration for publication. Of course, in some cases, articles with high similarity indexes - and there are not always many such articles - will be returned to authors to bring down the similarity index. Unfortunately, it would be wrong to assume that articles with high similarity indexes always represent plagiarised work. Perhaps not, as authors might have published their work "in-house" and the work might have been retained on a repository. In such cases, the articles would "match" the newly submitted articles to our journal, the South African Journal of Higher Education. The caution therefore is not to presume that articles with high similarity indexes are all plagiarised ones. In some cases, it could well be the case, but it would be improper to assume that Turnitin detects plagiarism. It does not. Instead, it gives an idea of how similar the work submitted is to what already exists on a repository somewhere else on the web. In this sense, we partially agree with Pooe and Dichaba (2019) that Turnitin is not a plagiarism detection software, but rather a plagiarism deterrent one. And yet, it would be equally wrong to assume that when articles have been returned, and indexes have been reduced, that plagiarism has not transpired. Dominant and pervading understandings of plagiarism lean towards reductionist understandings thereof - students and academics, alike, reduce plagiarism to the mere copying of text. Yet, plagiarism extends beyond mere replication and borrowing of text. Plagiarism is equally about laying claim to ideas that are not originally one's own; it is about adapting ideas that are not one's own, without acknowledging the original source.

It might be that Pooe and Dichaba (2019) are too ambitious in their consideration that Turnitin deters plagiarism. If the software only identifies similar words and sentences, it does not pass a judgment on the ideas or thoughts that constitute an article or thesis. It would be too presumptuous to assert that Turnitin deters plagiarism because it is quite possible to use someone else's ideas without recognition, and to reformulate and articulate those ideas into linguistic passages that would not be picked up by the software. It is not possible for Turnitin software - at least at this stage - to identify from where the ideas defrauded had come. Those using the software should not consider it a panacea for plagiarism problems in the academe. However, what similarity indexes reveal about scholarship, is that in the case where such indexes are real - that is, where academics have replicated work, which perhaps already exists somewhere else - the scholarship seems to be broken in the sense that such academics lack the capacity to re-articulate themselves differently; hence, they use existing phrases of work to 
conclude a piece of writing. This is also where Turnitin can be of assistance. However, that it necessarily reveals plagiarism would be too risky a position to assume.

Perhaps this is where Turnitin seems to be limited. And perhaps the limitation is not because of a technical deficiency, but rather because plagiarism within itself is symptomatic of something else - something which stems from a realm of (un)ethics, rather than literary theft. The point is perhaps the limitation presented by Turnitin is because plagiarism is, in fact, an ethical, rather than a mere literary violation. And despite our initial assertion that our purpose with this article is not to delve into a discussion of ethical dilemmas, it would appear that any type of reflection on the prevalence of plagiarism is necessarily earthed in what it means to write and act with integrity. There is widespread consensus that when academics and students write and produce text, that they do so on the shoulders of preceding scholars and theorists. The point being that what we come to know and write, comes into form and content through reading, listening and engaging with other texts and ideas - consciously or unconsciously. Whether or not we choose to acknowledge our sources, depends on how we understand ourselves as ethical beings - both in relation to our own writing, and in relation to those whose ideas came before ours.

\section{ON CHEATING IN ACADEMIC WRITING}

Over the years, we have encountered a few instances where academic cheating by students have been brought to our attention - that is, allegations that the work submitted by a particular student, is, in fact, not his or her own. In one particular instance, a principal had submitted an essay, which he had copied from another student, who also happened to be a teacher at his school. The teacher had in good faith allowed her boss, the principal, to read her essay, under the auspices that he simply wanted to see how she had approached a particular question. When the cheating became apparent, the teacher's despair was less about the copying of her work, than a violation of a trust, which she thought existed between her and the principal. In this scenario, the academic misrepresentation by the principal stemmed from an abuse of power between him and a member of his staff. But the way in which the matter degenerated, revealed ethical fault-lines, which exceeds instrumentalist interpretations of academic cheating.

What we have increasingly grown concerned about, particularly in our postgraduate work, are the possibilities of ghost-writing, also referred to as contract-writing. Ghost-writing or contract-writing involves soliciting the services of a secret writer, and then presenting that writing as one's own. Students in our department, for example, are required to provide brief preliminary proposals, when they apply for access into our Doctoral programme. We do this as a means to get a sense of a potential student's writing capacity - since the transition from a 
Masters to a Doctoral programme is a demanding one. Yet, we sometimes find that the type of writing we read from students after they have been accepted does not correlate with the type of writing when they applied - raising questions about who the original author actually is. There are two sets of problems here. On the one hand, there is a student, who is neither capacitated to enter a specific programme, nor in a position to learn anything, since he or she is not doing the actual work, and therefore has no reason to learn. Such a student would remain ignorant of the higher education discourse he or she would represent and advocate elsewhere. On the other hand, the person, who is doing the actual writing, is probably doing so for a fee, and is committing a serious academic crime. We cannot imagine that those assisted by ghost writers would ever meaningfully and rigorously enhance scholarship in the field of study. And, this is where the danger lies. The implications and repercussions of academic cheating are deepseated. The action of cheating is not contained within one piece of writing or the completion of a $\mathrm{PhD}$, for example. For instance, if a student cheats, and gets away with it, that cheating continues into another realm, as the student, who might pursue an academic career in which (s)he is expected to both produce and nurture scholarship in other students, will be challenged to produce publications on his or her own. How will this be done, what will the quality of this scholarship be, when, in the first instance, there was no scholarship?

\section{GOOGLE AND WIKIPEDIA “CUTTING AND PASTING”}

Undeniably, we are living in an advanced information age ranging from established university libraries to advanced e-learning technological information sources. It is quite possible to produce an article without even opening a hard copy of an academic book, as e-books are now freely available. However, it is also possible to access Google sources, including Wiki sources, to cut and paste others' ideas and then to make them one's own. In such cases, as averred by Du Plessis (2019), institutions should use quality assurance mechanisms to protect the academic integrity of institutions. Yet, although Du Plessis is correct, she does not take the argument further. Upholding academic integrity is not some instrumentalist exercise of behaviour modification, whereby people would be deterred from misrepresenting themselves and their academic work and then things will be resolved: no cheating, no fraudulent activities and no plagiarism. Such shameful acts in the academe can be prevented only when individuals take it upon themselves to change, and this change speaks as much to notions of scholarship as it does to ethical scholarship. As Amy Gutmann (2003) so aptly reminds us, unless individuals are going to change from inside, the promotion of academic integrity would not happen. At stake here, is not only an individual's academic integrity, but the integrity of the scholarship itself. If students and academics are cheating, and not producing their own work, and if they are laying 
claim to mastering this or that discipline (as symbolically recognised through the attainment of a $\mathrm{PhD}$ ) without actually having read or wrote, then scholarship becomes hollowed out, it becomes devoid of substance. And when others, like ourselves witness this, and remain quiet, then we become part of that hollow, and add to the overall undermining of what it means to be and act scholarly. Academics, therefore should bear witness by identifying the ills in and about academic perjury and dishonesty, and they should realise that such malpractices do not belong in highly prestigious spaces like higher education institutions.

\section{TOWARDS A CONCLUSION}

As we conclude, we recognise, as philosophers of education, that before we came into writing and into scholarship, volumes of ideas and new ways of thinking by unprecedented scholars from Aristotle to Ludwig Wittgenstein - set the tone and climate for the texts we produce today. We have stepped onto a terrain that has existed long before our first words found themselves inscribed on paper. More importantly, we are a part of a world, while not perfect, continues to remind us of great minds because of their regard for the integrity of thought and scholarship. At the same time we are not remiss of the neoliberalist discourses and agendas, which permeate every aspect of higher education. We are aware of the immense pressurised spaces of the academe, where notions of collegiality are often undermined by research production for the sake of production. But, we wish to caution - with great care - that as we write, we are putting into motion the reading matter (hopefully) of future generations that might bravely ask questions to which we have wilfully turned a blind eye. Our scholarship depends on what we write, it says something about who we are, and at the heart of who we are, should be love for what we do, and that means treating our scholarship with love and a love for knowledge.

\section{REFERENCES}

Du Plessis, I. 2019. "E-learning as the cornerstone to academic integrity in the $21^{\text {st }}$ Century." Unpublished Paper Presented at the Council on Higher Education Quality Promotion Conference: Promoting Academic Integrity in Higher Education, 26-28 February, CSIR International Convention Centre, Pretoria.

Gutmann, A. 2003. Identity and democracy. Princeton: Princeton University Press.

Pooe, M. and M. Dichaba. 2019. "Turnitin or Turnitout: An evaluation of the effectiveness of the plagiarism deterrent software." Unpublished Paper Presented at the Council on Higher Education Quality Promotion Conference: Promoting Academic Integrity in Higher Education, 26-28 February, CSIR International Convention Centre, Pretoria. 